\title{
Pengaruh Size, Age, Profitability, Leverage dan Sales Growth Terhadap Tax Avoidance
}

\author{
${ }^{1}$ Amanda Dhinari Permata, ${ }^{2}$ Siti Nurlaela, ${ }^{3}$ Endang Masitoh W \\ 1,2,3 Jurusan Akuntansi, Fakultas Ekonomi, Universitas Islam Batik Surakarta, Indonesia \\ ${ }^{1}$ Email korenpondensi: amandapermata40@gmail.com
}

Recieved: 28-03-2018 | Revised: 21-05-2018 | Accepted: 04-06-2018

\begin{abstract}
The purpose of this study was to examine the effect of Size, Age, Profitability, Leverage, Sales Growth on Tax Avoidance. The population which is the object of this research is the basic and chemical industry sectors listed on Indonesia Stock Exchange (BEI) in 2012 - 2016. The total population of 68 companies, this study obtained by purposive sampling technique which then resulted in 32 research samples for further investigation. The analysis technique used is logistic regression analysis. Based on data analysis and discussion can be concluded that Size, Age, Profitability, Leverage, and Sales Growth has no effect on Tax Avoidance. This means that the government succeeded in conducting Tax Amnesty program which has the impact of the company will not do Tax Avoidance.
\end{abstract}

Keywords: Size, Age, Profitability, Leverage, Tax Avoidance.

Saran sitasi: Permata, A., Nurlaela, S., \& Wahyuningsih, E. (2018). Pengaruh Size, Age, Profitability, Leverage dan Sales Growth Terhadap Tax Avoidance. Jurnal Akuntansi dan Pajak, 19(1), 10-20. doi:http://dx.doi.org/10.29040/jap.v19i1.171

DOI: http://dx.doi.org/10.29040/jap.v19i1.171

\section{Pendahuluan}

Rasio pajak yang dimiliki Indonesia berada kisaran $11 \%$ yang menempatkan Indonesia pada jajaran rasio pajak rendah dunia. Rasio ini jauh tertinggal di barisan negara menengah yaitu sebesar $14-15 \%$ dan negara maju yaitu sebesar 24-26\%. Apabila masalah penghindaran pajak dapat teratasi dan penguatan institusi pajak bisa terlaksana maka rasio pajak akan terus meningkat. Awal tahun sampai 31 Agustus 2017, realisasi penerimaan pajak telah mencapai $53,5 \%$ dari target Anggaran Pendapatan dan Belanja Negara Perubahan (APBNP) 2017 sebesar Rp 1.283,57 triliun. Penerimaan pajak Agustus 2017 mencapai Rp 685,6 triliun dengan angka pertumbuhan $10,23 \%$ dibandingkan tahun lalu. Rincian penerimaan pajak pada Agustus di antaranya $\mathrm{PPh}$ non migas Rp 378 triliun, PPN dan PPNBM sebesar Rp 267 triliun, PPh Migas Rp 35 triliun, pajak lainnya $\mathrm{Rp}$ 4,3 triliun, dan $\mathrm{PBB} \mathrm{Rp} 1,2$ triliun. Center for Indonesia Taxation Analysis (CITA) memperkirakan, penerimaan pajak tahun ini bisa mencapai 96\% dari target atau Rp 1.232 triliun (Direktorat Jenderal Pajak, 2017).

Penanam Modal Asing (PMA) di Indonesia yang selama 10 tahun terakhir tidak membayar pajak. Akibatnya, Indonesia mengalami kerugian hingga Rp 500 triliun dalam 10 tahun, para pengusaha asing tersebut tidak membayar pajak dengan klaim bahwa perusahaannya selalu mengalami kerugian. Padahal, jika dihitung seharusnya perusahaan tersebut membayar rata- 
rata Rp25 miliar dalam satu tahun (Sindonews, 2016).

Peraturan perpajakan untuk perusahaan multi nasional tidak lagi sesuai dengan perubahan bisnis global lintas Negara, kemudahan mobilitas bisnis, struktur perusahaan yang makin komplek dan perbedaan sistem hukum antar negara. Banyak perusahaan multi nasional yang melakukan Base Erosion and Profit Shifting (BEPS) untuk menghindari atau mengurangi kewajiban pajaknya pada suatu negara. BEPS mengacu pada upaya strategi penghindaran pajak dengan cara memanfaatkan gap kelemahankelemahan yang terdapat dalam peraturan perundang-undangan perpajakan (domestik) dan perbedaan sistem perpajakan antar negara. Perusahaan multinasional dapat mengalihkan keuntungan perusahaannya pada negara lain yang memiliki (tarif pajak) peraturan perpajakan yang lebih rendah.

Indonesia telah bersepakat untuk menerapkan the Automatic Exchange of Information (AEOI) dalam rangka mengurangi upaya-upaya penghindaran pajak tersebut. Pemerintah Indonesia antara lain telah menerbitkan Peraturan Pemerintah Pengganti UU (Perppu) No 1 Tahun 2017 tentang Akses Informasi Keuangan Untuk Kepentingan Perpajakan. Perppu ini telah disetujui untuk menjadi Undang-undang oleh Dewan Perwakilan Rakyat (DPR) Juli 2017. Hasil salah satu penelitian yang menunjukkan rendahnya jumlah pembayar pajak di Indonesia yang hanya sekitar $25 \%$ dari jumlah tenaga kerja dan sekitar $60 \%$ dari total wajib pajak yang melaporkan SPT tahun 2016. Hasil program tax amnesty juga mendukung data tersebut. Praktik-praktik penghindaran pajak lintas juridiksi juga terjadi dengan cara menyembunyikan aset di beberapa negara tax haven seperti Swiss, Hong Kong dan Singapura (Kementrian Keuangan Republik Indonesia, 2017).

Terdapat perbedaan kepentingan antara wajib pajak dan pemerintah, wajib pajak berusaha agar membayar pajak sekecil - kecilnya karena membayar pajak berarti mengurangi kemampuan ekonomis wajib pajak. Dana untuk penyelenggaraan pemerintahan sebagian berasal dari penerimaan pajak. Adanya perbedaan kepentingan ini menyebabkan wajib pajak cenderung untuk mengurangi jumlah pembayaran pajaknya, baik secara legal maupun illegal. Hal ini dimungkinkan jika ada peluang untuk melakukan Tax Avoidance.

Tax avoidance (penghindaran pajak) adalah upaya penghindaran pajak yang dilakukan secara legal dan aman bagi wajib pajak karena dilakukan dengan cara-cara yang tidak melanggar dan tidak bertentangan dengan ketentuan perpajakan, dimana metode dan teknik yang digunakan cenderung memanfaatkan kelemahan-kelemahan yang terdapat dalam ketentuan perpajakan (Pohan, 2016).

Tax Avoidance dapat dilakukan dengan memanfaatkan celah dalam peraturan perpajakan sehingga tidak melanggar hukum yang berlaku dan bisa membuat isu tersebut menjadi isu diskusi hingga saat ini menjadikan berlarut-larut tanpa ada titik temu. Meminimalisir praktik penghindaran pajak di Undang-undang perpajakan sudah dikenal peraturan specific anti avoidance rule dalam Pasal 18 Undang-undang Pajak Penghasilan, tetapi seiring semakin kompleksnya skema penghindaran pajak yang digunakan tidak mungkin dapat mencakup seluruh jenis transaksi penghindaran pajak. Pemilik perusahaan akan mendorong manajemen untuk melakukan tindakan pajak agresif untuk mengurangi beban pajak yang muncul (Chen et al, 2010)

Aktivitas Tax Avoidance dapat dipengaruhi oleh beberapa faktor-faktor yang mempengaruhi diantaranya adalah Size, Age, Profitability, Leverage, dan Sales Growth. Berbagai faktor sudah diteliti untuk mengetahui penyebab terjadinya Tax Avoidance. Penelitian dilakukan Lanis \& Richardson (2012), yang mendapatkan hasil penelitian bahwa variabel size atau ukuran perusahaan memiliki pengaruh positif dan signifikan terhadap tax avoidance. Begitu juga dengan penelitian Putra \& Merkusiwati (2016) mendapatkan hasil penelitian bahwa size berpengaruh positif dan signifikan pada tax avoidance. Akan tetapi penelitian yang dilakukan oleh 
Yuniarwati dkk (2017), Swingly \& Sukartha (2015), Wijayanti \& Merkusiwati, (2017) bahwa size atau ukuran perusahaan tidak berpengaruh.

Mahanani, Titisari, \& Nurlaela (2017) mendapatkan hasil penelitian bahwa umur perusahaan berpengaruh terhadap tax avoidance. Hal yang sama juga dilakukan oleh (Dewinta \& Setiawan, 2016) yang mendapatkan hasil penelitian bahwa umur perusahaan berpengaruh positif terhadap tax avoidance. Variabel ROA penelitian oleh Saifudin \& Yunanda (2016) mendapatkan hasil penelitian bahwa return on asset berpengaruh terhadap penghindaran pajak. Kurniasih \& Sari (2013), serta Waluyo, Basri, \& Rusli (2014) yang mendapatkan hasil penelitian bahwa Return on Assets (ROA) berpengaruh signifikan secara parsial terhadap tax avoidance hal yang tidak sejalan dengan penelitian dilakukan oleh Rosalia \& Sapari (2017), Diawati (2017), Ambarukmi \& Diana (2017), Cahyono, Andini, \& Raharjo (2016) bahwa ROA tidak berpengaruh. Selanjutnya, Variabel Leverage penelitian yang dilakukan oleh Rachmithasari (2015) yang mendapatkan hasil penelitian bahwa Leverage berpengaruh positif terhadap tax avoidance, sedangkan penelitian yang dilakukan Dharma \& Ardiana (2016) mendapatkan hasil penelitian bahwa leverage berpengaruh negatif terhadap tax avoidance. Saifudin \& Yunanda (2016) mendapatkan hasil penelitian bahwa leverage berpengaruh negatif pada tax avoidance. Mahanani \& Titisari (2016) mendapatkan hasil penelitian bahwa sales growth berpengaruh positif terhadap tax avoidance. Sedangkan penelitian yang dilakukan Swingly \& Sukartha, (2015) mendapatkan hasil penelitian bahwa sales growth tidak berpengaruh pada Tax Avoidance.

Berdasarkan hasil penelitian-penelitian sebelumnya, diketahui bahwa terdapat perbedaan yang menyimpulkan hasil pengaruh Size, Age, Profitability, Leverage, dan Sales Growth terhadap Tax Avoidance. Penelitian ini berusaha menemukan bukti mengenai pengaruh Size, Age, Profitability, Leverage, dan Sales Growth terhadap Tax Avoidance yang dilakukan dengan memperbarui dan menambah tahun pengamatan selama 2012-2016 yang digunakan dalam penelitian dengan pertimbangan bahwa periode tersebut akan diperoleh data yang lebih baru. Penelitian ini fokus pada lima variabel independen yang memiliki pengaruh terhadap Tax Avoidance yaitu Size, Age, Profitability, Leverage, dan Sales Growth.

\section{Tinjauan Pustaka}

\section{Size Terhadap Tax Avoidance}

Menurut Hasibuan, ukuran perusahaan adalah suatu skala dimana dapat diklasifikasikan besar kecil perusahaan menurut berbagai cara, antara lain: total aset, log size, penjualan dan kapitalisasi pasar, dan lain-lain (Sari, Kalbuana, \& Jumadi, 2016). Semakin besar perusahaan maka semakin besar total aset yang dimilikinya. Dalam melakukan tax planning untuk upaya menekan beban pajak seminimal mungkin, perusahaan dapat mengelola total aset perusahaan untuk mengurangi penghasilan kena pajak yaitu dengan memanfaatkan beban penyusutan dan amortisasi yang timbul dari pengeluaran untuk memperoleh aset tersebut karena beban penyusutan dan amortisasi dapat digunakan sebagai pengurang penghasilan kena pajak perusahaan. Hasil penelitian Sari, Kalbuana, \& Jumadi (2016) menunjukkan ukuran perusahaan berpengaruh terhadap penghindaran pajak.

H1 : Size berpengaruh terhadap Tax Avoidance

\section{Age Terhadap Tax Avoidance}

Seiring dengan berjalannya waktu, perusahaan akan menjadi tidak efisien menurut Waelchli \& Loderer (2010) dalam jurnalnya yang berjudul "Firm Age and Performance". Perusahaan yang mengalami penuaan harus mengurangi biaya termasuk biaya pajaknya akibat pengalaman dan pembelajaran yang dimiliki oleh perusahaan serta pengaruh perusahaan lain baik dalam industri yang sama maupun berbeda. Perusahaan dengan jangka waktu operasional lebih lama juga akan membuat perusahaan lebih ahli dalam mengatur pengelolaan pajaknya yang berdasarkan pengalamanpengalaman sebelumnya. Sumber daya manusia yang ahli dalam perpajakan diperlukan untuk menekan beban pajak perusahaan sehingga 
pengelolaan pajak yang dilakukan oleh perusahaan dapat maksimal. Secara logika, semakin lama jangka waktu operasional suatu perusahaan, semakin banyak pengalaman yang dimiliki oleh perusahaan tersebut dan sumber daya manusia yang dimiliki semakin ahli dalam mengatur dan mengelola beban pajaknya sehingga kecenderungan untuk melakukan tax avoidance semakin tinggi. Mahanani \& Titisari (2016) mendapatkan hasil penelitian bahwa umur perusahaan berpengaruh terhadap tax avoidance. Hal yang sama juga dilakukan oleh Dewinta \& Setiawan (2016) yang mendapatkan hasil penelitian bahwa umur perusahaan berpengaruh positif terhadap tax avoidance.

H2 : Age berpengaruh terhadap Tax Avoidance

\section{Profitability Terhadap Tax Avoidance}

Berdasarkan hasil penelitian yang dilakukan Darmawan \& Sukartha (2014) bahwa ROA berpengaruh terhadap Tax Avoidance dikarenakan perusahaan mampu mengelola asetnya dengan baik salah satunya dengan memanfaatkan beban penyusutan dan amortisasi, serta beban penelitian dan pengembangan yang dapat dimanfaatkan sebagai pengurang penghasilan kena pajaknya serta memperoleh keuntungan dari insentif pajak dan kelonggaran pajak lainnya sehingga perusahaan tersebut terlihat melakukan penghindaran pajak. Hasil penelitian Maharani \& Suardana (2014) menemukan hasil bahwa ROA berpengaruh terhadap Tax Avoidance.

H3 : Profitability berpengaruh terhadap Tax Avoidance

\section{Leverage Terhadap Tax Avoidance}

Leverage merupakan rasio yang digunakan untuk mengukur sejauh mana aset perusahaan dibiayai dengan utang (Waluyo, Basri, \& Rusli, 2014). Artinya, berapa besar beban utang yang ditanggung perusahaan dibandingkan dengan asetnya. Perusahaan dimungkinkan menggunakan utang untuk memenuhi kebutuhan operasional dan investasi perusahaan. Akan tetapi, utang akan menimbulkan beban tetap (fixed rate of return) yang disebut dengan bunga. Beban bunga yang ditanggung peusahaan dapat dimanfaatkan sebagai pengurang penghasilan kena pajak perusahaan untuk menekan beban pajaknya. Dengan begitu bahwa semakin tinggi nilai dari rasio leverage, berarti semakin tinggi jumlah pendanaan dari utang pihak ketiga yang digunakan perusahaan dan semakin tinggi pula biaya bunga yang timbul dari utang tersebut. Biaya bunga yang semakin tinggi akan memberikan pengaruh berkurangnya beban pajak perusahaan. Semakin besar utang maka laba kena pajak akan menjadi lebih kecil karena insentif pajak atas bunga utang semakin besar (Darmawan \& Sukartha, 2014). Hal tersebut membawa implikasi meningkatnya penggunaan utang oleh perusahaan. Hasil penelitian Waluyo, Basri, \& Rusli (2014), Nursari, Diamonalisa \& Sukarmanto (2017) menunjukkan leverage berpengaruh terhadap Tax Avoidance.

$\mathrm{H} 4$ : Leverage berpengaruh terhadap Tax Avoidance

\section{Pertumbuhan Penjualan Terhadap Tax} Avoidance

Penelitian Budiman \& Setiyono (2012) menemukan bahwa terdapat pengaruh signifikan Sales Growth terhadap terhadap Tax Avoidance. H5 : Sales Growth berpengaruh terhadap Tax Avoidance

\section{Metode Penelitian}

Penelitian ini menggunakan pendekatan kuantitatif. Penelitian dilakukan pada Perusahaan Sektor Industri Dasar dan Kimia yang Terdaftar Di BEI tahun 2012-2016. Sumber Data kuantitatif dalam penelitian ini adalah angka-angka laporan keuangan Perusahaan Sektor Industri Dasar dan Kimia yang Terdaftar Di BEI tahun 2012-2016. Data kualitatif dalam penelitian ini adalah daftar nama-nama perusahaan Sektor Industri Dasar dan Kimia yang terdaftar di BEI. Penelitian ini menggunakan data sekunder eksternal. Data sekunder eksternal yaitu data yang diperoleh peneliti secara tidak langsung melalui perantara, seperti orang lain atau dokumen (Sugiyono, 2013). Data sekunder eksternal dalam penelitian ini adalah laporan keuangan tahunan Perusahaan Sektor Industri Dasar dan Kimia yang Terdaftar Di BEI tahun 2012-2016 yang 
diperoleh melalui website BEI yaitu www.idx.co.id

Populasi dalam penelitian ini adalah seluruh Perusahaan Sektor Industri Dasar dan Kimia yang Terdaftar di BEI tahun 2012-2016 yang berjumlah 68 perusahaan. Sampel dalam penelitian ini adalah semua Perusahaan Sektor Industri Dasar dan Kimia yang Terdaftar Di BEI tahun 2012-2016, namun perusahaan yang tidak sesuai dengan kriteria yang ditetapkan peneliti akan dikeluarkan dari sampel. Penentuan sampel dalam penelitian ini didasarkan pada metode non-probability sampling dengan teknik purposive sampling.

Teknik Analisis Data yang digunakan Statistik Deskriptif, Kelayakan Model Regresi, Menilai Kesesuaian Keseluruhan Model (Overall Model Fit), Uji Koefisien Determinasi (Nagelkerke R Square), Uji Multikolinieritas, Uji Matriks Klasifikasi, Uji Omnibus, Model Regresi Logistik, Uji Wald

\section{Hasil dan Pembahasan}

\subsection{Hasil penelitian}

Populasi objek penelitian ini adalah perusahaan sektor industri dasar dan kimia yang terdaftar pada Bursa Efek Indonesia (BEI) tahun
2012-2016. Jumlah Populasi 68 perusahaan, perusahaan yang datanya tidak lengkap sebanyak 36 perusahaan, maka sampel yang digunakan berjumlah 32 perusahaan.

Berdasarkan Tabel 2, hasil analisis dengan menggunakan statistik deskriptif variabel CETR memiliki rata-rata sebesar 0,66 dan standar deviasi 0,474. Minimum sebesar 0 pada tahun 2012, nilai maksimum sebesar 1 dimiliki oleh perusahaan KBRI (Kertas Basuki Rachmat Indonesia Tbk) pada tahun 2014. Variabel Size memiliki rata-rata sebesar 27,9064 dan standar deviasi 1,72009. Variabel Size menunjukkan nilai minimum sebesar 23,58 dimiliki oleh perusahaan BTON (Beton Jaya Manunggal Tbk) pada tahun 2014, Perusahaan CPIN (Charoen Pokphand Indonesia Tbk) pada tahun 2012 memiliki nilai maksimum sebesar 32,11. Variabel Age menunjukkan rata-rata sebesar 18,0937 dan standar deviasi 6,64159. Perusahaan BAJA (Saranacentral Bajatama Tbk) pada tahun 2012 menunjukkan nilai minimum sebesar 1, nilai maksimum sebesar 27 dimiliki oleh perusahaan INTP (Idocement Tunggal Prakasa Tbk) pada tahun 2016. Variabel Profitability

Tabel 1. Pemilihan Sampel

\begin{tabular}{clc}
\hline No & \multicolumn{1}{c}{ Kriteria } & Jumlah \\
\hline 1 & $\begin{array}{l}\text { Perusahaan sektor industri dasar dan kimia } \\
\text { Perusahaan mempublikasikan laporan keuangan auditan per } 31\end{array}$ & 68 \\
2 & $\begin{array}{l}\text { Desember namun tidak konsisten dan tidak lengkap atau tidak } \\
\text { menyajikan informasi yang berkaitan dengan variabel penelitian serta }\end{array}$ & $(15)$ \\
& mengalami delisting selama pengamatan \\
3 & $\begin{array}{l}\text { Perusahaan manufaktur yang tidak menggunakan rupiah (Rp) sebagai } \\
\text { mata uang pelaporan }\end{array}$ & $(13)$ \\
4 & $\begin{array}{l}\text { Perusahaan manufaktur dengan nilai CETR lebih dari satu } \\
\text { Jumlah Sampel Perusahaan } \\
\text { Tahun Observasi }\end{array}$ & $(8)$ \\
& Jumlah Observasi 2012-2016 & 32 \\
\hline
\end{tabular}

\section{Hasil Uji Deskriptif}

Tabel 2. Hasil Uji Deskriptif

\begin{tabular}{lrrrr}
\hline \multicolumn{1}{c}{ Variabel } & \multicolumn{1}{c}{ Min } & \multicolumn{1}{c}{ Max } & \multicolumn{1}{c}{ Mean } & Std. Dev \\
\hline Size $\left(\mathrm{X}_{1}\right)$ & 23,58 & 32,11 & 27,9064 & 1,72009 \\
Age $\left(\mathrm{X}_{2}\right)$ & 1,00 & 27,00 & 18,0937 & 6,64159 \\
Profitability $\left(\mathrm{X}_{3}\right)$ & $-54,85$ & 83,37 & 5,6208 & 12,10765 \\
Leverage $\left(\mathrm{X}_{4}\right)$ & 0,03 & 663,71 & 50,2164 & 74,13547 \\
Sales growth $\left(\mathrm{X}_{5}\right)$ & $-1,00$ & 5,95 &, 1074 &, 71195 \\
CETR (Y) & 0 & 1 &, 66 &, 474 \\
\hline
\end{tabular}


mempunyai rata-rata sebesar 5,6208 dan standar deviasi 12,10765. Variabel Profitability yang mempunyai nilai minimum $-54,85$ adalah perusahaan IKAI (Inti Keramik Alam Asri Industri Tbk) pada tahun 2016, nilai maksimum sebesar 83,37 dimiliki oleh perusahaan DPNS (Duta Pertiwi Nusantara Tbk) pada tahun 2014. Variabel Leverage rata-rata sebesar 0,04 dan standar deviasi 74,13547. Perusahaan yang memiliki nilai minimum sebesar 0,03 pada variabel leverage dimiliki oleh perusahaan AMFG (Asahimas Flat Glass Tbk) pada tahun 2016, nilai maksimum sebesar 663,71 dimiliki oleh perusahaan JPFA (Japfa Comfeed Indonesia Tbk ) pada tahun 2014. Variabel Sales Growth menunjukkan rata-rata 0,1074 dan standar deviasi 0,71195 . Perusahaan yang memiliki nilai minimum sebesar -1 adalah perusahaan AMFG (Asahimas Flat Glass Tbk) pada tahun 2016, nilai maksimum sebesar 5,95 dimiliki oleh perusahaan KBRI (Kertas Basuki Rachmat Indonesia Tbk) pada tahun 2015.

\section{Menilai Kelayakan Model Regresi}

Tabel 3. Hasil Uji Hosmer and Lemeshow Test

\begin{tabular}{ccc}
\hline Chi-Square & df & Sig. \\
\hline 14,198 & 8 & 0,077 \\
\hline
\end{tabular}

Pada Tabel 3, Hosmer and Lemeshow's Goodness of Fit Test menunjukkan bahwa ChiSquare sebesar 14,198 dengan df 8 dan tingkat signifikan 0,077. Hasil tersebut menunjukkan nilai signifikansi lebih besar dari 0,05, jadi berdasarkan hasil tersebut berarti model mampu memprediksi nilai observasinya atau dapat dikatakan model dapat diterima karena cocok dengan data observasi.

\section{Menilai Keseluruhan Model (Overall Model} Fit )

Tabel 4. Hasil Uji Overall Model Fit

\begin{tabular}{cc}
\hline -2Log Likelihood Awal & 204,596 \\
\hline -2Log Likehood Akhir & 192,987 \\
\hline Penurunan -2LL & 11,609
\end{tabular}

Pada Tabel 4, membandingkan -2log likelihood awal dengan nilai -2log likehood akhir. Pada nilai awal sebesar 204,596 setelah dimasukkan 5 variabel mengalami penurunan menjadi 192,987 dengan kata lain nilai -2LL mengalami penurunan sebesar 11,609. Dengan demikian menandakan bahwa model lebih baik atau dengan kata lain model yang dihipotesiskan fit dengan data.

\section{Koefisien Determinasi (Negelkerke R Square)}

Tabel 5. Hasil Uji Negelkerke R Square

\begin{tabular}{cc}
\hline Nagelkerke R Square & 0,097 \\
\hline Nilai Nagelkerke R square sebesar & 0,097
\end{tabular}
artinya variabel dependen yang dapat dijelaskan oleh variabel independen adalah sebesar 9,7\% dan sisanya sebesar 90,3\% dapat dijelaskan oleh variabel-variabel lain diluar model penelitian.

Tabel 6. Hasil Uji Multikolinieritas

\begin{tabular}{lccccc}
\hline \multicolumn{1}{c}{ Variabel } & Tollerance & Standar & VIF & Standar & Keterangan \\
\hline Size $\left(\mathrm{X}_{1}\right)$ & 0,961 & $>0,10$ & 1,041 & $<10$ & Bebas Multikolinearitas \\
Age $\left(\mathrm{X}_{2}\right)$ & 0,943 & $>0,10$ & 1,061 & $<10$ & Bebas Multikolinearitas \\
Profitability $\left(\mathrm{X}_{3}\right)$ & 0,967 & $>0,10$ & 1,035 & $<10$ & Bebas Multikolinearitas \\
Leverage $\left(\mathrm{X}_{4}\right)$ & 0,980 & $>0,10$ & 1,021 & $<10$ & Bebas Multikolinearitas \\
Sales growth $\left(\mathrm{X}_{5}\right)$ & 0,991 & $>0,10$ & 1,009 & $<10$ & Bebas Multikolinearitas \\
\hline
\end{tabular}

Tabel 7. Hasil Uji Matrik Klasifikasi

\begin{tabular}{llccc}
\hline & Observed & \multicolumn{2}{c}{ Predicted CETR (Y) } & Percentage \\
\cline { 2 - 3 } & $\begin{array}{c}\text { Tidak melakukan Tax } \\
\text { Avoidance }\end{array}$ & $\begin{array}{c}\text { Melakukan Tax } \\
\text { Avoidance }\end{array}$ & $\begin{array}{c}\text { Correct } \\
\text { Tidak melakukan Tax }\end{array}$ \\
$\begin{array}{l}\text { CETR } \\
\text { Avoidance }\end{array}$ & 2 & 52 & 3,7 \\
Melakukan Tax & Avoidance & 5 & 101 & 95,3 \\
Overall Percentage & & & 64,4 \\
\hline
\end{tabular}




\section{Uji Multikolinieritas}

Berdasarkan hasil uji multikolinearitas pada Tabel 6 menunjukkan bahwa Size, Age, Profitability, Leverage, dan Sales Growth memiliki nilai tolerance diatas 0,1 dan nilai VIF dibawah 10 maka model regresi bebas dari multikolinearitas di dalam regresinya.

\section{Matrik Klasifikasi}

Tabel 7, menjelaskan bahwa persentase variabel yang diprediksi sebesar $64,4 \%$ adalah baik, dan dari perbandingan antara kedua nilai mengindikasikan tidak terdapatnya masalah homoskedastisitas (asumsi model logit).

\section{Uji Omnibus}

Tabel 8. Hasil Uji Omnibus

\begin{tabular}{ccc}
\hline Sig & Standar & Keterangan \\
0,041 & $<0,05$ & Berpengaruh \\
\hline
\end{tabular}

Dilihat pada Tabel 8, hasil Omnimbus Test of Model Coefficients mejelaskan nilai sig $<0,05$ jadi semua hipotesis diterima artinya secara bersama-sama kelima variabel independen berpengaruh terhadap Tax Avoidance.

\section{Analisis Regresi Logistik}

Tabel 9. Hasil Uji Regresi Logistik

\begin{tabular}{lc}
\hline Variabel & Koefisien \\
\hline Constant & 4,977 \\
Size $\left(\mathrm{X}_{1}\right)$ &,- 105 \\
Age $\left(\mathrm{X}_{2}\right)$ &,- 049 \\
Profitability $\left(\mathrm{X}_{3}\right)$ &, 011 \\
Leverage $\left(\mathrm{X}_{4}\right)$ &,- 012 \\
Sales growth $\left(\mathrm{X}_{5}\right)$ &, 148 \\
\hline
\end{tabular}

Pengujian terhadap koefisien regresi logistik tesebut menghasilkan model berikut ini:

$\mathrm{Y}=4,977-0,105 \mathrm{X} 1-0,49 \mathrm{X} 2+0,011 \mathrm{X} 3$ -

$$
0,012 X 4+0,148 X 5
$$

a. Konstanta yang diperoleh dari hasil olah data sebesar 4,977 maka tax Avoidance akan meningkat sebesar $497,7 \%$.

b. Koefisien regresi variabel size bernilai 0,105 . Hal ini berarti apabila variabel size naik sebesar $1 \%$ dengan asumsi variabel yang lainnya tetap, maka akan diikuti penurunan tax avoidance sebesar 0,105 atau $10,5 \%$. c. Koefisien regresi variabel age bernilai -0,49. Hal ini berarti apabila variabel age naik sebesar $1 \%$ dengan asumsi variabel yang lainnya tetap, maka akan diikuti penurunan tax avoidance sebesar -0,49 atau 49\%.

d. Koefisien regresi variabel profitability bernilai 0,011. Hal ini berarti apabila variabel profitability naik sebesar $1 \%$ dengan asumsi variabel yang lainnya tetap, maka akan diikuti kenaikan $\operatorname{tax}$ avoidance sebesar 0,011 atau 1,1\%.

e. Koefisien regresi variabel leverage bernilai 0,012 . Hal ini berarti apabila variabel leverage naik sebesar $1 \%$ dengan asumsi variabel yang lainnya tetap, maka akan diikuti penurunan tax avoidance sebesar 0,012 atau $1,2 \%$.

f. Koefisien regresi variabel sales growht bernilai 0,148. Hal ini berarti apabila variabel sales growht naik sebesar $1 \%$ dengan asumsi variabel yang lainnya tetap, maka akan diikuti kenaikan tax avoidance sebesar 0,148 atau $14,8 \%$.

\section{Uji Wald}

Tabel 10. Hasil Uji Wald

\begin{tabular}{lccc}
\hline \multicolumn{1}{c}{ Variabel } & Sig & Standar & Keterangan \\
\hline Size $\left(\mathrm{X}_{1}\right)$ & 0,297 & $<0,05$ & $\mathrm{H} 1$ ditolak \\
Age $\left(\mathrm{X}_{2}\right)$ & 0,096 & $<0,05$ & $\mathrm{H} 2$ ditolak \\
Profitability $\left(\mathrm{X}_{3}\right)$ & 0,453 & $<0,05$ & $\mathrm{H}$ 3 ditolak \\
Leverage $\left(\mathrm{X}_{4}\right)$ & 0,055 & $<0,05$ & $\mathrm{H} 4$ ditolak \\
Sales growth $\left(\mathrm{X}_{5}\right)$ & 0,623 & $<0,05$ & $\mathrm{H}$ 5 ditolak \\
\hline
\end{tabular}

Pengujian hipotesis dilakukan dengan cara membandingkan antara tingkat signifikan (sig) dengan tingkat kesalahan $(\alpha)=5 \%$. Disimpulkan bahwa variabel Size, Age, Profitability, Leverage, dan Sales Growth tidak berpengaruh terhadap Tax Avoidance

\subsection{Pembahasan}

\section{Pengaruh Size Terhadap Tax Avoidance}

Hipotesis pertama menyatakan Size berpengaruh terhadap Tax Avoidance Hasil pengujian menunjukkan tingkat signifikansi 0.297 dengan $(\alpha)=5 \%$. Berarti bahwa nilai signifikansi $>0,05$ Sehingga dapat disimpulkan bahwa variabel Size tidak berpengaruh terhadap Tax Avoidance. 
Dengan demikian, hipotesis pertama tidak dapat diterima (ditolak).

Hal ini sejalan dengan penelitian yang dilakukan oleh Annisa (2017), Yuniarwati dkk (2017), Wijayanti \& Merkusiwati (2017) yang menemukan bahwa size (ukuran perusahaan) tidak berpengaruh dan tidak signifikan terhadap Tax Avoidance (penghindaran pajak). Hasil uji hipotesis pertama pada penelitian ini mengindikasikan bahwa besar atau kecilnya size (ukuran) perusahaan tidak mempengaruhi Tax Avoidance.

Perusahaan besar atau kecil tidak berpengaruh pada Tax Avoidance, karena perusahaan patuh untuk tidak melanggar ketentuan perpajakan yang berlaku. Perusahaan tidak ingin mengambil resiko direpotkan dengan proses pemeriksaan atau dikenakan sanksi yang dapat menyebabkan citra perusahaan berdampak buruk. Pengawasan yang dilakukan oleh pihak fiskus tidak hanya pada perusahaan besar tetapi perusahaan kecil juga dapat menarik perhatian fiskus agar mengikuti ketentuan perpajakan yang berlaku dan dikenakan pajak yang sesuai dengan peraturan yang berlaku.

\section{Pengaruh Age Terhadap Tax Avoidance}

Hipotesis kedua menyatakan Age berpengaruh terhadap Tax Avoidance. Hasil pengujian menunjukkan tingkat signifikansi 0.096 dengan $(\alpha)=5 \%$ Sehingga dapat disimpulkan bahwa variabel Age tidak berpengaruh terhadap Tax Avoidance. Penelitian ini berbeda dengan penelitian yang dilakukan Mahanani \& Titisari (2016) hal ini disebabkan karena perbedaan sampel yang diambil. Penelitian ini sama-sama menggunakan sampel perusahaan sektor industri dasar dan kimia namun periode yang diambil berbeda pada Mahanani \& Titisari (2016) menggunakan periode 2013-2015 sedangkan dalam penelitian ini menggunakan periode 2012-2016. Hal ini berarti semakin lama perusahaan berdiri tidak berpengaruh terhadap tax avoidance. Hal ini dikarenakan adanya program tax amnesty yang mewajibkan semua perusahaan untuk mengikuti program terbeut maka perusahaan dengan umur tua atau perusahaan barupun sekarang taat akan peraturan perpajakan dan sulit untuk melakukan tax avoidance.

Pengaruh Profitability Terhadap Tax Avoidance

Hipotesis ketiga menyatakan Profitability berpengaruh terhadap Tax Avoidance dari hasil pengujian untuk variabel Profitability menunjukkan tingkat signifikansi 0.453 dengan $(\alpha)=5 \%$ nilai signifikansi >0,05 dapat disimpulkan bahwa variabel Profitability tidak berpengaruh terhadap Tax Avoidance.

Hasil penelitian Rosalia \& Sapari (Rosalia \& Sapari, 2017), Nursari, Diamonalisa, \& Sukarmanto (2017), Diawati (Diawati, 2017), Rosalia \& Sapari (2017), Ambarukmi \& Diana (2017), Cahyono, Andini, \& Raharjo (2016), mengenai ROA yang tidak berpengaruh terhadap penghindaran pajak mendukung penelitian ini. Tax Avoidance merupakan aktivitas berisiko, sehingga manajemen tidak akan mengambil risiko dalam meminimalkan risiko investasinya. Tax Avoidance juga dapat membebankan biaya yang signifikan, termasuk biaya yang dibayarkan kepada konsultan pajak, waktu yang dihabiskan untuk penyelesaian audit pajak, denda reputasi, dan denda yang dibayarkan kepada otoritas pajak.

\section{Pengaruh Leverage Terhadap Tax Avoidance}

Hipotesis keempat menyatakan Leverage berpengaruh terhadap Tax Avoidance Hasil pengujian menunjukkan tingkat signifikansi 0.055 dengan $(\alpha)=5 \%$ Berarti bahwa nilai signifikansi > 0,05 Sehingga dapat disimpulkan bahwa variabel Leverage tidak berpengaruh terhadap Tax Avoidance Dengan demikian, Hipotesis keempat tidak dapat diterima (ditolak).

Hal ini sejalan dengan penelitian yang dilakukan oleh Kurniasih \& Sari (2013), Ngadiman \& Puspitasari (2013), Dewinta \& Setiawan (2016), Putra \& Merkusiwati (2016), Saifudin \& Yunanda (2016), Pradipta \& Supriyadi (2014), Pustipa \& Febrianti (2017) bahwa Leverage tidak berpengaruh terhadap Tax Avoidance.

Perusahaan menggunakan hutang tidak semata-mata untuk menciptakan pendapatan, ada kemungkinan hutang digunakan untuk berinvestasi jangka panjang, sehingga beban bunga tidak 
timbul perperiode pada laporan keuangan, jadi tidak dapat digunakan sebagi pengurang beban pajak yang harus dibayarkan perusahaan. Dimungkinkan juga untuk memenuhi kebutuhan operasional dan investasi perusahaan. Akan tetapi, utang akan menimbulkan beban tetap (fixed rate of return) yang disebut dengan bunga. Semakin besar utang maka laba kena pajak akan menjadi lebih kecil karena insentif pajak atas bunga utang semakin besar.

\section{Pengaruh Sales Growth Terhadap Tax Avoidance}

Hipotesis kelima menyatakan Sales Growth berpengaruh terhadap Tax Avoidance Hasil pengujian menunjukkan tingkat signifikansi 0,081 dengan $(\alpha)=5 \%$ Sehingga dapat disimpulkan bahwa variable Sales Growth tidak berpengaruh terhadap Tax Avoidance. Hal ini sesuai dengan hasil penelitian Melisa \& Tandean (2017), Oktaviyani \& Munandar (2017), Rosalia \& Sapari (2017), Swingly \& Sukartha, (2015), Mahanani, Titisari, \& Nurlaela (2017), Wulansari \& Dewi (2017) Sales Growth tidak berpengaruh terhadap Tax Avoidance.

Sales Growth yang baik di dalam suatu perusahaan akan membuat ukuran perusahaan semakin besar. Semakin besarnya ukuran perusahaan akan semakin membuat total aset di dalam perusahaan semakin besar pula. Keadaan ini akan membuat perusahaan sulit dalam melakukan tax saving melalui tax planning perusahaan.

\section{Kesimpulan}

Berdasarkan analisis data dan pembahasan, dapat ditarik kesimpulan bahwa Size, Age, Profitability, Leverage, dan Sales Growth tidak berpengaruh terhadap Tax Avoidance. Hal ini berarti pemerintah berhasil melakukan program Tax Amnesty yang mempunyai dampak perusahaan tidak akan melakukukan Tax Avoidance.

\section{Ucapan Terimakasih}

Terimakasih kepada, kedua orang tua saya Ibu Tri dan Bapak Sukadi dan semua yang telah berperan membantu saya.

\section{Daftar Pustaka}

Ambarukmi, K. T., \& Diana, N. (2017). Pengaruh Size, Leverage, Profitability, Capital
Inttensity Ratio Dan Activity Ratio Terhadap Effective Tax Rate (ETR). E_Junal Ilmiah Riset Akuntansi V. 1. 06. No. 17 Pebruari 2017 ISSN : 2302-7061.

Annisa. (2017). Pengaruh Return On Asset, Leverage, Ukuran Perusahaan Dan Koneksi Politik Terhadap Penghindaran Pajak. JOM Fekon, Vol. 4 No.1 (Februari) 2017 .

Budiman, J., \& Setiyono. (2012). Pengaruh Karakter Eksekutif terhadap Penghindaran Pajak (Tax Avoidance).

Cahyono, D. D., Andini, R., \& Raharjo, K. (2016). Pengaruh Komite Audit, Kepemilikan Institusional, Dewan Komisaris, Ukuran Perusahaan (Size), Leverage (DER) Dan Profitabilitas (ROA) Terhadap Tindakan Penghindaran Pajak (Tax Avoidance) Pada Perusahaan Perbankan Yang Listing BEI Periode Tahun 2011 - 201. Journal Of Accounting, Volume 2 No.2 Maret 2016 .

Chen et al. (2010). Are Family Firms more Tax Aggressive than Non Nonfamily. Journal of Financial Economics. 91, (1), 41-61. Research Collection School Of Accountancy .

Darmawan, I. G., \& Sukartha, I. M. (2014). Pengaruh Penerapan Corporate Governance,Leverage, Return On Assets dan Ukuran Perusahaan pada Penghindaran Pajak. EJurnal Akuntansi Universitas Udayana. 9.1 (2014): 143-161 .

Dewinta, I. A., \& Setiawan, P. E. (2016). Pengaruh Ukuran Perusahaan, Umur Perusahaan,Profitabilitas, Leverage, Dan Pertumbuhan Penjualan Terhadap Tax Avoidance. E-Jurnal Akuntansi Universitas Udayana Vol.14.3. Maret (2016): 1584-1613 ISSN: 2302-8556 .

Dharma, I. M., \& Ardiana, P. A. (2016). Pengaruh Leverage, Intensitas Aset Tetap, Ukuran Perusahaan, Dan Koneksi Politik Terhadap Tax Avoidance. E-Jurnal Akuntansi Universitas Udayana Vol.15.1 April (2016): 584-613 ISSN: 2302-8556 .

Diawati, A. A. (2017). Analisis Pengaruh Good Corporate Governance,Karakter Eksekutif, Profitabilitas, Dan Ukuran Perusahaan Terhadap Tax Avoidance.

Direktorat Jenderal Pajak. (2017, Juli Jum'at). Pajak dan Dukungan Publik. Retrieved 
Oktober Kamis, 2017, from http://www.pajak.go.id/content/article/pajak-dandukungan-publik.

Kementrian Keuangan Republik Indonesia. (2017, September Rabu). Informasi Keuangan Penting Untuk Tingkatkan Kepatuhan Membayar Pajak. Retrieved Oktober 23, 2017, from https://www.kemenkeu.go.id/publikasi/berita/wamenkeu-informasikeuangan-penting-untuk-tingkatkankepatuhan-membayar-pajak/

Kurniasih, T., \& Sari, M. M. (2013). Pengaruh Return On Assets,Leverage, Corporate Governance, Ukuran Perusahaan Dan Kompensasi Rugi Fiskal Pada Tax Avoidance. Buletin Studi Ekonomi, Volume 18, No. 1, Februari 2013 ISSN 1410-4628.

Lanis, R., \& Richardson, G. (2012). "Corporate social responsibility and tax aggressiveness: a test of legitimacy theory". Accounting, Auditing \& Accountability Journal .

Mahanani, A., \& Titisari, K. H. (2016). Pengaruh Ukuran Perusahaan Dan Sales Growth Terhadap Tax Avoidance. Seminar Nasional Dan Call Paper Fakultas Ekonomi Uniba Surakarta .

Mahanani, A., Titisari, K., \& Nurlaela, S. (2017). Pengaruh Karakteristik Perusahaan, Sales Growth Dan CSR Terhadap Tax Avoidance. Seminar Nasional IENACO - 2017.

Maharani, I. G., \& Suardana, K. A. (2014). Pengaruh Corporate Governance, Profitabilitas dan Karakteristik Eksekutif pada Tax Avoidance Perusahaan Manufaktur. E-jurnal Akuntansi Universitas Udayana 9.2 (2014) : 525-539 Perusahaan Manufaktur. E-Jurnal Akuntansi Universitas Udayana 9.2 ISSN: 2302-8556, 526-539.

Melisa, M., \& Tandean, V. A. (2017). FaktorFaktor Yang Mempengaruhi Penghindaran Pajak (Tax Avoidance). Jurnal Akuntansi Bisnis Vol.8 No.1.

Ngadiman, \& Puspitasari, C. (2013). Pengaruh Leverage, Kepemilikan Institusional, Dan Ukuran Perusahaan Terhadap Penghindaran Pajak (Tax Avoidance) Pada Perusahaan Sektor Manufaktur Yang Terdaftar Di Bursa Efek Indonesia 2010-2012. Jurnal Akuntansi
Volume XVIII. No. 03, September 2014: 408-421.

Nursari, M., Diamonalisa, \& Sukarmanto, E. (2017). Pengaruh Profitabilitas Dan Kepemilikan Institusional Terhadap Tax Avoidance. Prosding Akuntansi.

Oktaviyani, R., \& Munandar, A. (2017). Effect of Solvency, Sales Growth, and Institutional Ownership on Tax Avoidance with Profitability as Moderating Variables in Indonesian Property and Real Estate Companies. Binus Business Review, 8(3), November 2017, 183-188 ISSN: 2087-1228 E-ISSN: 24769053.

Pohan, C.A. (2016). Manajemen Perpajakan (Strategi Perencanaan Pajak dan Bisnis) Edisi Revisi. Jakarta: PT Gramedia Jakarta.

Pradipta, D. H., \& Supriyadi. (2014). Pengaruh Corporate Social Responsibility (CSR), Profitabilitas, Leverage, dan Komisaris Independen Terhadap Praktik Penghindaran Pajak.

Pustipa, D., \& Febrianti, M. (2017). Faktor Factor Yang Mempengaruhi Penghindaran Pajak Pada Perusahaan Manufaktur Di Bursa Effek Indoesia. Jurnal Bisnis Dan Akuntansi Vol.19 No.1 Juni 2017 ISSN : 1410-9875.

Putra, I. G., \& Merkusiwati, N. K. (2016). Pengaruh Komisaris Independen, Leverage, Size Dan Capital Intensity Ratio Pada Tax Avoidance. E-Jurnal Akuntansi Universitas Udayana Vol.17.1. Oktober (2016): 690-714 ISSN: 2302-8556.

Rachmithasari, A. F. (2015). Pengaruh Return On Assets, Leverage, Corporate Governance, Ukuran Perusahaan Dan Kompensasi Rugi Fiskal Pada Tax Avoidance.

Rinaldi, \& Cheisviyanny, C. (2015). Pengaruh Profitabilitas, Ukuran Perusahaan Dan Kompensasi Rugi Fiskal Terhadap Tax Avoidance. Seminar Nasional Ekonomi Manajemen Dan Akuntansi (Snema) Fakultas Ekonomi Universitas Negeri Padang ISBN: 978-60217129-5-5.

Rosalia, Y. (2017). Pengaruh Profitabilitas, Likuiditas Dan Corporate Governance Terhadap Penghindaran Pajak. Jurnal Ilmu dan Riset Akuntansi Volume 6, Nomor 3, Maret 2017 ISSN : 2460-0585. 
Rosalia, Y., \& Sapari. (2017). Jurnal Ilmu dan Riset Akuntansi Volume 6, Nomor 3, Maret 2017 ISSN : 2460-0585 .

Saifudin, \& Yunanda, D. (2016). Determinasi Return on Asset, Leverage, Ukuran Perusahaan, Kompensasi Rugi Fiskal dan Kepemilikan Institusi Terhadap Penghindaran Pajak. Jurnal Penelitian Ilmu Ekonomi WIGA Vol. 6 No. 2, September 2016.

Sari, N., Kalbuana, N., \& Jumadi, A. (2016). Pengaruh Konservatisme Akuntansi, Kualitas Audit, Ukuran Perusahaan Terhadap Terhadap Penghindaran Pajak. Seminar Nasional dan The 3rd Call for Syariah Paper ISSN 2460-0784 .

Sindonews. (2016). Retrieved Oktober Kamis, 2017, from https://ekbis.sindonews.com/read/1094705/33/2000-perusahaan-asingmangkir-bayar-pajak-ri-rugi-rp500-triliun458565786. 23 Oktober 2017.

Sugiyono. (2013). Metode Penelitian Bisnis. Bandung: CV Alfabeta.

Swingly, C., \& Sukartha, I. M. (2015). Pengaruh Karakter Eksekutif, Komite Audit, Ukuran Perusahaan, Leverage Dan Sales growth Pada Tax Avoidance. E-Jurnal Akuntansi Universitas Udayana 10.1 (2015): 47-62 ISSN: 2302-8556 .
Waelchli, U., \& Loderer, C. (2010). Firm age and performance. MPRA Paper No. 26450,7. November 2010 .

Waluyo, T. M., Basri, Y. M., \& Rusli. (2014). Pengaruh Return On Asset, Leverage, Ukuran Perusahaan, Kompensasi Rugi Fiskal, dan Kepemilikan Institusi Terhadap Penghindaran Pajak.

Wijayanti, Y. C., \& Merkusiwati, N. K. (2017). Pengaruh Proporsi Komisaris Independen, Kepemilikan Institusional, Leverage, Dan Ukuran Perusahaan Pada Penghindaran Pajak. E-Jurnal Akuntansi Universitas Udayana Vol.20.1. Juli (2017): 699-728 ISSN: 2302-8556.

Wulansari, N., \& Dewi, H. R. (2017). Pengaruh Kepemilikan Institusional, Proporsi Dewan Komisaris Independen, Komite Audit, Konservatisme Akuntansi, Pertumbuhan Penjualan Dan Leverage Terhadap Penghindaran Pajak. Simposium Nasional Akuntansi XX, Jember, 2017 .

Yuniarwati dkk. (2017). Factors That Influence Tax Avoidance in Indonesia Stock Exchange. Chinese Business Review, Oct. 2017, Vol. 16, No. 10, 510-517. 